\title{
The Role of Corporate Reputation in Determining Investor Satisfaction and Loyalty
}

\author{
Sabrina Helm \\ Strategic Marketing Department, Witten/Herdecke University, Witten, Germany
}

Corporate Reputation Review, Vol. 10, No. 1, pp. 22-37 (C) 2007 Palgrave Macmillan Ltd, $1363-3589 \$ 30.00$

\begin{abstract}
Prior research suggests that corporate reputation is a determinant of initial investment decisions, possibly leading to detrimental stock choices. Its effect on established investor relationships, namely investor satisfaction and loyalty, are novel research areas. The present paper discusses findings of a study among German investors of a publicly traded company that put into perspective the aforementioned detrimental choice-effect, the impact of reputation on individual investor behavior and reveals a diversity of loyalty effects of corporate reputation. Corporate Reputation Review (2007) 10, 22-37. doi:10.1057/palgrave.crr.1550036
\end{abstract}

KEYWORDS: corporate reputation; investor satisfaction; investor loyalty; reputation measure; structural equation modelling; partial least squares

\section{INTRODUCTION}

Today, one of the forces accelerating corporate reputation's value to firms is the vast need for investment capital. If investors believe reputation conveys important information about the profit and long-term potential of a company (eg Fombrun and Shanley, 1990; Brown and Perry, 1994), the 'reputation of a firm increasingly will influence its appeal as an investment choice' (Chajet, 1997: 20). While this area of research has been of interest to investor relations managers for decades, the effects of the company's reputation on the attitudes and behavior of non-institutional shareholders has hardly been dealt with empirically. Although some evidence might have been accumulated by accounting firms, it tends to deal with institutional investors and remain proprietary, establishing a need to further investigate individual investors' responses to corporate reputation.

According to studies in behavioral finance, individual investors' predilection to judge companies as better investment opportunities because they are perceived as highly reputed might be a fallacy. In current studies, corporate reputation is investigated as a determinant in the formation of risk and return expectations. Investors tend to assume that good investment opportunities come from 'good' companies, that is from companies with a high reputational rating (Shefrin and Statman, 1995; Shefrin, 2001). Relying on survey data published by Fortune magazine on the reputation of major US companies, Shefrin finds that 'Investors who judge that good stocks are stocks of good companies will associate good stocks with both safe stocks and high future earnings' (2001: 179). This defies empirical evidence that proves the opposite to be true. Investors err if they expect safe stocks and high future earnings (only) from 'good', or highly reputed companies (Shefrin, 2001). There might be, however, more to reputation's role in determining investor behavior than this possibly misleading choice-effect.

Generally, investor behavior can be analyzed in terms of initial share purchases 
(eg Shefrin, 2001), in terms of switching behavior in the context of portfolio optimization (eg Spurgin and Tamarkin, 2005), or in the context of 'sticking to stocks' (eg disposition effects, Shefrin and Statman, 1984). From the perspective of the individual publicly traded firm, it may be beneficial when individual investors keep their shares on a long-term basis. Leaving detailed analyses to future research contributions, we propose that investor loyalty leads to stable relationships that reduce the risk of a (hostile) takeover; to less volatility in share prices; to the possibility of implementing long-term strategies instead of quarter-based activities; to a reduction of costs induced by investor relations. Among others, satisfaction with investment outcomes (ie the fulfillment of investor expectations) and corporate reputation are interpreted as determinants of investor loyalty.

The present paper investigates the construct of reputation and its influence on investors, especially their satisfaction and loyalty, using primary data and sociopsychological methodologies. Three research questions are investigated:

1. How can corporate reputation, satisfaction, and loyalty be conceptualized taking an individual investor perspective?

2. Does corporate reputation influence individual investor's satisfaction and loyalty?

3. What do the findings add to the notion of a detrimental effect of reputation on individual investor decision-making?

In order to address these research questions, the paper is structured as follows: In the next section, the relevant literature and the theoretical background of the study are presented. In the subsequent section, the conceptualization of the constructs and scales are outlined and the empirical research design is described in the fourth section. In the fifth section, the data analysis is reported and major findings are discussed in the penultimate section. Limitations of the present study and suggestions for future research are presented in the final section.

\section{DEFINITIONS AND THEORETICAL BACKGROUND}

\section{Defining Corporate Reputation}

A growing body of literature has led to an abundance of alternative definitions of corporate reputation. Gotsi and Wilson, for instance, highlight numerous viewpoints and conclude that, in general, corporate reputation should be viewed as 'a stakeholder's overall evaluation of a company over time' (2001: 29). Reputation is a socially shared impression, a consensus about how a firm will behave in any given situation (Bromley, 2002; Sandberg, 2002). It is based on a set of collectively held beliefs about a company's ability and willingness to satisfy the interests of various stakeholders (Fombrun, 1996). Recent work has emphasized the plurality of perceptions and representations concerning a company, but it has mainly centered on the customers', employees', and the general public's perspectives. While analysts' view on reputation has sporadically been taken into account (Fombrun et al., 2000; Mazzola et al., 2004), reputational perceptions by individual investors are a novel field of research.

\section{Research Streams on the Effects of Corporate Reputation in Financial Markets}

Extant research suggests that - from the firm's point of view - a good reputation allows it to charge premium prices, attract better applicants for its workforce, attract investors, and lower its cost of capital, making it one of the firm's most important intangible assets (eg Hammond and Slocum, 1996; Fombrun, 1996; Little and Little, 2000). Larsen (2002) goes so far as to claim 
that companies manage their reputations mainly for financial reasons. Concerning stakeholders' point of view, a major stream of research focuses on reputation's potential as a signal that serves to reduce customers' uncertainty considering product quality (eg Shapiro, 1982), uncertainty of (future) employees with regard to employer characteristics (eg Cable and Graham, 2000), uncertainty of players on the capital market concerning future stock performance (eg Baker and Haslem, 1973), etc.

With regard to corporate reputation's role among actors on financial markets, three streams of research are noteworthy. First, the dominant literature stream in this field deals with the link between financial performance of the firm and its reputation (see among many, Sobol and Farrelly, 1988; Hammond and Slocum, 1996). To a large part, these studies conclude that firms with relatively good reputations are better able to sustain superior profit outcomes over time (eg Roberts and Dowling, 2002), although these findings are far from being undisputed (eg Sabate and Puente, 2003). A subgroup of these studies deal with the impact of reputation on ratings in financial markets. Fombrun for example observes that 'companies with higher stocks of reputational capital tend to be assigned better ratings' (1996: 119) and Deephouse introduces the concept of 'financial reputation' which he defines as 'the general evaluation of a company's financial prospects made by the financial rating industry' (1997: 69).

A second stream relevant to field of interest is the vast literature on the role of reputation in individual investment decision making. For instance, MacGregor et al. (2000) claim that in IPO's, reputation and an affective evaluation provide the basis for investor buying decisions. Brown mentions that "poor reputation signals to investors that disaster lurks, and that when it strikes, those companies will not have the necessary public support they need to weather the storm'
(1998: 279). Shefrin and Statman (1995) as well as Srivastava et al. (1997) find evidence that current or potential investors perceive a company with a good reputation to be less risky than companies with equivalent financial performance, but a less well-established reputation. In spite of equivalent risk and return prospects, highly reputed firms profit from investors who are willing to pay more for their shares than for shares of less reputed firms (Larsen, 2002), and who expect a lower return on investment (Srivastava et al., 1997).

Bondt (1998) and Gardberg (2001) caution that corporate reputation and share price do not necessarily correlate. This finding has been substantiated by Shefrin and Statman (1995) who claim that 'good' companies do not necessarily issue 'good' stocks (ie stocks with share price increases above average). Corporate reputation serves not only as a performance signal, though, but can become a choice criterion itself as individual investors are not exclusively interested in high dividends or share appreciation (Hunt, 1952). Although return is the prime factor in investment decisions (Bondt, 1998; Chajet, 1997), corporate reputation climbs up the scale of importance. 'The more stockholders there are, the more people will be sensitive to the reputations of the companies in which they are investing' (Chajet, 1997: 22 ), especially in post-Enron times (Dowling, 2004). As Hanson and Stuart remark, 'shareholders may be interested in profit but they will also share the shame and declining profits associated with a deteriorating corporate reputation which is now increasingly the subject of media and public scrutiny' (2001: 141). Social and psychological aspects determine individual investment behavior to a considerable extent (Shefrin, 2001; Goldberg and Nitzsch, 2001), especially because of the ever-increasing amount of information available to investors. "The complexity of the task may drive the respondent to weigh affective cues more 
Owing to the novelty of the research area,

heavily than technical indicators' (MacGregor et al., 2000: 110), possibly increasing the importance of corporate reputation as a determinant of investor behavior.

A last and somewhat loosely related field of research focuses on the impact of corporate reputation or image on the attitudes and behaviors of customers in financial markets, namely banking services. For instance, Bloemer and de Ruyter (1998) as well as Martensen et al. (2000) find empirical evidence that corporate image influences customers satisfaction and loyalty in retail banking. Albeit not necessarily congruent, information on customer attitudes and behaviors in this specific product/service environment may provide insights into reputation's role in determining individual investors' reactions to reputation. While these findings will be pointed out in more detail below, it can be summarized that albeit there is numerous evidence on the role corporate reputation plays in different contexts of financial markets, individual investors' perceptions of corporate reputation have hardly been focused. In such a setting, corporate reputation signifies an investor's perception of the estimation in which 'his/her' firm is held by its stakeholders in general which results from the company's ability and willingness to perform according to its promises to these different stakeholder groups.

\section{The Loyalty of Individual Investors}

Investor behavior has been the subject of diverse studies in the field of behavioral finance (eg Shleifer, 2000; Shefrin, 2002; Shiller, 2003) that approach the subject with psychological or sociological theories. While initial investment decisions are analyzed, the long-term behavior of investors as reflected in their loyalty is often disregarded. This is striking insofar as there is a widespread managerial and academic interest in the loyalty of other stakeholder groups, such as customers and employees. we model investor loyalty and its link to reputation and satisfaction equivalently to findings in customer settings, thereby interpreting investors as customers for the firm's 'most important product, namely, the company itself' (Ferris, 1989: 173). Consequently, definitions of the constructs might be based on prior work in marketing research. According to Oliver, the term 'customer loyalty' signifies 'a deeply held commitment to rebuy or repatronize a preferred product or service consistently in the future' (1997: 392). Dick and Basu understand it to be the 'favorable correspondence between relative attitude and repeat patronage' (1994: 102). Presumably, affective predispositions and repetitive behavior also form different kinds of investor loyalty. As financial decisions are taken in situations of high complexity and high uncertainty that preclude reliance on predefined rules, the individual is constrained to rely on intuition and emotion (Kahneman and Riepe, 1998). In a financial services setting, Bloemer and de Ruyter (1998) define customers' loyalty as a behavioral response that is a function of psychological processes resulting in commitment, which again may be understood as the pledging or binding of the individual customer to his/her bank of choice. Affective evaluation must be considered one of the most fundamental psychological processes in financial decision making (MacGregor et al., 2000). Furthermore, loyalty can also be understood as a behavior because individuals usually act according to an affective predisposition. Consequently, affective loyalty should be viewed as an antecedent to behavioral loyalty. In an investment context, this behavioral element does not become manifest in repatronage but in the will and the actions taken to continue and intensify the existing relationship to a firm. For instance, behavioral loyalty might be reflected in the holding period of shares, the purchase of additional shares of the same 
firm, advising other investors to buy the shares.

Many studies have been published on the relationship of satisfaction and loyalty in customer settings. While both constructs seem to be linked inextricably, their relationship is asymmetric and satisfaction is not the only, and sometimes also an unreliable, precursor to loyalty (Oliver, 1999). This is also supported by a number of studies in retail banking that find satisfaction to be a main determinant of customer loyalty (Hallowell, 1996; Levesque and McDougall, 1996; Bloemer and de Ruyter, 1998). As existing and empirically tested theories in customer behavior cannot be transferred to an investor context without further investigation, the hypothesized link between investor satisfaction and loyalty deserves empirical study. Satisfaction is defined as the result of a favorable correspondence between a customer's expectations and his/her experiences with a firm (Churchill and Surprenant, 1982), and the same expectancy-disconfirmation paradigm might be applied to investors.

In customer settings, investigations of reputation as a determinant of loyalty have led to inconsistent results and remained a matter of debate (Bloemer and de Ruyter, 1998). Fombrun is convinced that 'reputation breeds customer loyalty' (1996: 78) and also, Nguyen and Leblanc (2001) and Anderson and Sullivan (1993) take reputation as an important determinant of loyalty. Yoon et al. (1993) and Abdullah et al. (2000) find a positive relationship between corporate reputation and the intention to buy a firm's products, and Martensen et al. (2000) report that corporate image is a main driver of customer satisfaction and loyalty in retail banking. Andreassen and Lindestad (1998) do not support the hypothesized direct impact of corporate image (interpreted synonymously to reputation) on loyalty, and also the study results discussed by Bloemer and de Ruyter (1998) initially do not support the hypothesized direct impact of corporate image on bank customers' satisfaction and loyalty but show that this effect is mediated by perceived quality. The authors also point out that - as an input for customer evaluations - image perceptions should precede satisfaction and loyalty. All studies at hand focus customer settings whereas no primary studies have been undertaken to determine the impact of reputation on investor satisfaction and loyalty.

The impact of reputation on investor satisfaction and loyalty may be explained by Festinger's (1957) theory of cognitive dissonance and self-perception theories (eg Bem, 1967). If an investor purchased shares of a highly esteemed firm, the favorable public perception of the firm might reinforce his stock choice, his self-perceived competence in investment decisions, his self-esteem, leading to satisfaction and possibly longer holding periods of the stock. If another investor bought stock from a firm with a bad reputation, the negative public perception of the stock might lead to cognitive dissonance and a generally more negative attitude towards the stock. This might cause her to reconsider her decision, have a negative impact on perceived satisfaction, and the investor might be more inclined to sell the stock in order to reduce any psychological pain induced by cognitive dissonance. Furthermore, the representativeness effect studied in behavioral finance (eg Shefrin, 2001; Goldberg and Nitzsch, 2001) might lead to premature selling of stock from badly reputed firms while inducing longer holding periods for shares from highly reputed firms. Individual investors are prone to stereotyping (Goldberg and Nitzsch, 2001) so that a firm with a good reputation is believed to be a good investment as well (Shefrin, 2001), reinforcing satisfaction scores and the loyalty of investors.

Summarizing the conceptual arguments, we therefore hypothesize (see Figure 1 for 
an illustration):

$\mathbf{H}_{1}$ : Individual investors' satisfaction is positively influenced by the degree of reputation as perceived by the investor.

$\mathbf{H}_{2}$ : Individual investors' affective loyalty to a firm is positively influenced by

a. the degree of investor satisfaction;

b. the degree of corporate reputation as perceived by the investor.

$\mathbf{H}_{3}$ : Individual investors' behavioral loyalty to a firm is positively influenced by

a. the degree of investor satisfaction;

b. the degree of corporate reputation as perceived by the investor.

$\mathbf{H}_{4}$ : Individual investors' behavioral loyalty to a firm is positively influenced by

the degree of their affective loyalty.

\section{SCALE DEVELOPMENT}

Whether all types of stakeholders base their perceptions of reputation on the same fundamental set of dimensions or on specific expectations is controversial (Bromley, 2002; Fombrun et al., 2000). In a preliminary study on corporate reputation as perceived by institutional investors, Mazzola et al. (2004) found that this stakeholder group evaluates reputation according to the dimensions relevant to other stakeholders (as for instance represented in one of the dominant measures of reputation, the Reputation Quotient ${ }^{S M}$; Fo- mbrun et al., 2000), plus information on the governance structure of the firm and its investor relations. Whether this is also true for individual investors is uncertain. Individual investors often do not possess the necessary expertise to understand governance issues, and they rarely contact investor relations departments (Mazzola et al., 2004).

Owing to the lack of empirical concepts for reputation as perceived by individual investors, investor satisfaction, and loyalty, novel measures are developed for our study. For developing the measurement models, the methodology proposed by Diamantopoulos and Winklhofer (2001) was followed. The first step in scale development is content specification, that is the definition of the constructs. From its diverse stakeholders' views, corporate reputation captures a combination of social and economic contributions that a company makes. As a consequence, rankings of companies that are based on a cluster of different corporate associations representing different stakeholders' expectations regarding the activities of a firm (eg product quality, use of employee talent, corporate social responsibility) have become the dominant approach to measure corporate reputation (Wartick, 2002; Berens and Riel, 2004). Existing scales on reputation (such as Fortune's Most Admired Company Index and the Reputation Quotient), satisfaction, and loyalty, two focus group interviews, and 10 in-depths interviews with individual investors provided input

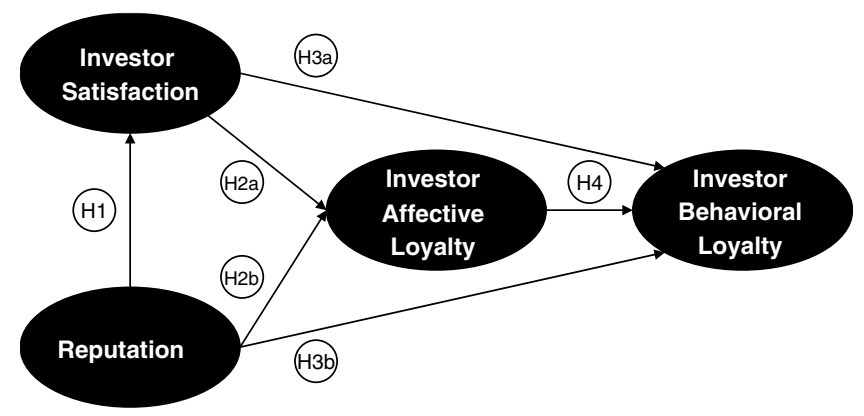

Figure 1: The conceptual model 
for construct conceptualization. Following this detailed procedure was supposed to grant content validity of the constructs - the kind of validity Rossiter (2002) claims to be most essential when defining measurement models. Furthermore, corporate reputation could be defined taking into account input by the potential respondents (Berens and Riel, 2004).

Potential indicators for the measures were identified by looking for items commonly used in prior construct models, and by integrating the results of the interviews. Interestingly, individual investors did not specifically emphasize financial aspects as a dominant dimension of the reputation construct. The list of possible indicators was then further refined including an item-sort task that showed how well the items tapped into their constructs (Anderson and Gerbing, 1991). Finally, questionnaires were administered to 20 investors in a 'think aloud' answer mode. The 10 remaining reputation indicators, four indicators for investors' satisfaction, and four indicators for each of the loyalty constructs were then included in the final survey. In accordance with Rossiter (2002), bipolar 7- or 5-point scales were used (for details on wording and scales, see Table 1).

In structural equation modeling, every construct or latent variable is assigned a set of indicators that may be reflective or formative leading to different epistemic structures of the constructs (eg Bollen and Lennox, 1991; Jarvis et al., 2003; MacKenzie et al., 2005; Helm, 2005). In the reflective case, the unobserved latent variable effects the indicators, meaning that all indicators 'measure the same thing and should covary at a high level if they are good measures of the underlying variable' (Bagozzi, 1994: 331). If the latent variable is thought to be a construct of all of its indicators - like an index or ranking - it needs to be measured formatively. 'Formative indicators give rise to the unobserved theoretical construct. In this case the empirical indicators produce or contribute to the construct' (Fornell, 1982: 8). We therefore decided to model corporate reputation and investor satisfaction with formative indicators, affective and behavioral loyalty were modeled as reflective constructs.

Conceptualizing reputation as a formative construct means that it is thought to be an aggregation of all its indicators such as product quality, quality of management, etc. This implies that because of the quality of its products, a firm has a good reputation; because of the quality of its management, it has a good reputation, etc. The same applies to the measure of satisfaction that is also seen as a summation of a firm's performances such as the amount of dividends paid to shareholders, the information policy of the firm, etc. In accordance with the literature (Andreassen, 1994; Oliver, 1997), both types of loyalty were conceptualized as reflective constructs. Increasing loyalty of an investor will usually result in a variety of different attitudinal and behavioral consequences. The more loyal, the more often the investor might refer the shares to others, buy more shares of the same company, and the more $\mathrm{s} /$ he will be willing to keep shares on a longterm basis. $\mathrm{S} / \mathrm{He}$ will show the entirety of the possible characteristics of loyal investors including a positive personal disposition towards the firm.

\section{RESEARCH DESIGN AND SAMPLE STRUCTURE}

Knowledge on investor satisfaction, loyalty, and reputation as perceived by individual investors is scarce, and the interplay of these constructs is a novel research area. Therefore, the aim of the empirical study was to explain variance resulting from different levels of perceived reputation, satisfaction, and loyalty; it was not to explain variances resulting from differences of the constructs in different industries or firms. Therefore, the study was restricted to one company and its individual investors. This was also necessary because we had to cooperate closely with a company 
Table 1: Information on the measurement models

\begin{tabular}{|c|c|c|c|c|c|c|}
\hline 1 & 2 & 3 & 4 & 5 & 6 & 7 \\
\hline Indicato & Description & weight $_{o}{ }^{1}$ & $t$-value & weight $_{r}{ }^{1}$ & $t$-value & \\
\hline \multicolumn{7}{|c|}{ Indicators for corporate reputation (formative construct) ${ }^{2}$} \\
\hline$x_{1}$ & Quality of products & 0.126 & 2.213 & 0.144 & 2.505 & \\
\hline$x_{2}$ & Value for money of products & 0.144 & 2.076 & 0.138 & 1.801 & \\
\hline$x_{3}$ & Commitment to protecting the environment & 0.137 & 1.661 & 0.156 & 1.874 & \\
\hline$x_{4}$ & Corporate success & 0.390 & 5.682 & 0.403 & 5.628 & \\
\hline$x_{5}$ & Treatment of employees & -0.120 & 1.238 & & & \\
\hline$x_{6}$ & Customer orientation & 0.060 & 0.773 & & & \\
\hline$x_{7}$ & Commitment to charitable and social issues & 0.264 & 2.508 & 0.246 & 2.800 & \\
\hline$x_{8}$ & Financial performance & 0.061 & 0.655 & & & \\
\hline$x_{9}$ & Qualification of management & 0.245 & 2.723 & 0.247 & 2.893 & \\
\hline$x_{10}$ & Credibility of advertising claims & 0.207 & 2.988 & 0.227 & 3.228 & \\
\hline \multicolumn{7}{|c|}{ Indicators for investor satisfaction (formative construct) ${ }^{3}$} \\
\hline$y_{1}$ & Amount of dividends paid & 0.353 & 6.186 & 0.365 & 5.919 & \\
\hline$y_{2}$ & Development of share prices & 0.082 & 1.229 & & & \\
\hline$y_{3}$ & Information policy concerning individual investors & 0.213 & 3.149 & 0.228 & 3.514 & \\
\hline \multirow[t]{2}{*}{$y_{4}$} & Evaluation of $\mathrm{x}$-shares as an investment & 0.580 & 7.750 & 0.620 & 9.357 & \\
\hline & & loadingo & $t$-value & loading & $t$-value $e_{\mathrm{r}}$ & $\begin{array}{l}\text { item } \\
\text { reliability } \\
\end{array}$ \\
\hline \multicolumn{7}{|c|}{ Indicators for investor behavioral loyalty (reflective construct) ${ }^{4}$} \\
\hline \multicolumn{7}{|c|}{ Composite reliability: 0.832 ; Average variance extracted: 0.555} \\
\hline$y_{5}$ & $\begin{array}{l}\text { Are you going to purchase more shares of } \\
\text { company } \mathrm{x} \text { within the next three years? }\end{array}$ & 0.676 & 23.800 & 0.675 & 24.873 & 0.456 \\
\hline$y_{6}$ & Are you going to hold your shares on a long term basis? & 0.802 & 45.572 & 0.802 & 43.531 & 0.643 \\
\hline$y_{7}$ & Would you refer company x's shares to others? & 0.802 & 44.421 & 0.803 & 44.368 & 0.645 \\
\hline$y_{8}$ & $\begin{array}{l}\text { Are you going to sell your } \mathrm{x} \text {-shares within the } \\
\text { next } 12 \text { months? }\end{array}$ & -0.689 & 17.356 & -0.690 & 16.775 & 0.476 \\
\hline \multicolumn{7}{|c|}{ Indicators for investor affective loyalty (reflective construct) ${ }^{5}$} \\
\hline \multicolumn{7}{|c|}{ Composite reliability: 0.892; Average variance extracted: 0.675} \\
\hline$y_{9}$ & To what extent do you feel bonded to company $\mathrm{x}$ ? & 0.833 & 50.525 & 0.834 & 51.120 & 0.700 \\
\hline$y_{10}$ & $\begin{array}{l}\text { To what extent would you regret if company } \mathrm{x} \text { and its } \\
\text { products were no longer available? }\end{array}$ & 0.806 & 47.006 & 0.806 & 42.880 & 0.650 \\
\hline$y_{11}$ & $\begin{array}{l}\text { As a shareholder, to what extent do you identify with } \\
\text { company } x \text { ? }\end{array}$ & 0.851 & 82.283 & 0.851 & 79.601 & 0.724 \\
\hline$y_{12}$ & $\begin{array}{l}\text { To what extent are you interested in the welfare of } \\
\text { company } x \text { ? }\end{array}$ & 0.794 & 37.645 & 0.794 & 35.114 & 0.630 \\
\hline
\end{tabular}

${ }^{1} \mathrm{o}$ stands for the original model including all indicators and paths; $r$ stands for the refined model including only the significant indicators and paths.

${ }^{2}$ Question: 'Please indicate, what kind of reputation does company $\mathrm{x}$ have in the public concerning the following attributes?'; Scale: $1=$ 'a very good reputation', $7=$ 'a very bad reputation'; scale entirely verbalized.

${ }^{3}$ Question: 'How would you rate your experiences with x concerning the following attributes?'; Scale: 1='very good experiences', 7='very bad experiences'; scale entirely verbalized.

${ }^{4}$ Scale for item $\gamma_{5}-\gamma_{8}: 1=$ 'yes, very likely', $5=$ 'no, not likely at all'; scale entirely verbalized; Scale for items $\gamma_{9}-\gamma_{12}: 1=$ 'to a very high extent', $5=$ 'not at all'; scale entirely verbalized. 
that possesses data of its individual investors. Most German corporations use bearer shares, not registered shares. Typically, individual investors remain unknown to the company unless it uses the annual general shareholder meeting and investor relations efforts to build up a database of its shareholders. This is still rather rare as 'shareholder relationship management' is as yet not commonly implemented in most German firms. A wellknown international consumer goods producer (fast-moving consumer goods such as detergent, and cosmetics) was willing to cooperate and provided the addresses of 1,120 individual investors.

A standardized questionnaire was sent to all of these 1,120 individual investors. The response rate amounted to 59 per cent (665 responses) which is very satisfying for a written survey (Dillman, 2000). As some questionnaires missed relevant data, the effective sample size was reduced to 657 usable questionnaires.

As the model to be tested contains formative and reflective constructs, partial least squares (PLS) was used for data analysis; the software package used was PLS-Graph. PLS allows for incorporating formative as well as reflective measurement models and is distribution-free (Jöreskog and Wold, 1982; Fornell and Bookstein, 1982).

\section{RESULTS}

In a first step, we analyzed the formative and reflective measurement models. The results are shown in Table 1. An evaluation of the formative measurement models is based on the weights and $t$-values of the indicators. 'The weights provide information as to what the makeup and relative importance are for each indicator in the creation/formation of the component' (Chin, 1998: 307). In Table 1 , weights that are not significant at $p=0.05$ are marked in gray (columns 3 and 4). One indicator of the satisfaction construct and three of the reputation indicators have weights below 0.1 and one has a negative sign making it necessary to consider scale purification. It has to be noted that the literature is inconsistent concerning the elimination of formative indicators (Diamantopoulos and Winklhofer, 2001). We follow Jöreskog and Wold (1982), Seltin and Keeves (1994), and MacKenzie et al. (2005) who suggest to remove weak indicators in order to build parsimonious models. This procedure reduces the satisfaction construct to three items and the reputation construct to seven items (see Table 1).

Concerning formative indicators, multicollinearity has to be investigated as the formative measurement model is based on a multiple regression (Diamantopoulos and Winklhofer, 2001). In the dataset, the highest value for the variance inflation factor (VIF) was 1.86 for reputation which is far below the common cut-off threshold of 10 (Kleinbaum et al., 1998). The VIF could be computed by correlating the indicators to a single-item overall measure of reputation (the question was: 'Does company $\mathrm{x}$ have a good or bad reputation in the public?', measured on a 7-point scale from 'a very good reputation' to 'a very bad reputation'). The highest indicator correlations were 0.580 for the reputation construct and 0.638 for satisfaction, so multi-collinearity should not pose a serious problem.

An evaluation of the reflective measures of loyalty is based on the loadings, $t$-values, and item reliability of each indicator. As all of the indicators feature a loading above or approaching the common threshold of 0.7 , scale purification is not deemed necessary (Baumgartner and Homburg, 1996). The whole set of loyalty items was subjected to an exploratory factor analysis with varimax rotation (Hair et al., 1998), resulting in a KMO-value of 0.85 . As could be expected, two dimensions were identified for loyalty: one contained all affective items, the other included all behavioral indicators. As hypothesized, two separate latent variables have to be integrated in the structural model. The 
$0.342([0.558 \times 0.252 \times 0.318]+[0.558 \times 0.445]+$ $[0.384 \times 0.318] \cong 0.342)$. The direct path $d$ from reputation to affective loyalty is stronger than the direct effect of satisfaction onto affective loyalty (path $b$ ). To test the strength of these relationships, we use the procedure explained by Cohen et al. (2003). This test is used to investigate the significance of the difference between dependent correlation coefficients determined from the same sample. The relationship between satisfaction and affective loyalty $\left(\beta_{11}=0.252\right)$ is significantly weaker $(z=-3.857 ; p=0.01)$ than the relationship between reputation and affective loyalty $\left(\gamma_{21}=0.384\right)$. Following the same procedure, we also test the strength of the relationships between satisfaction and the two kinds of loyalty. The relationship between satisfaction and affective loyalty $\left(\beta_{11}=0.252\right)$ is only just significantly weaker $(z=-2.986$; $p=0.01)$ than the relationship between reputation and behavioral loyalty $\left(\beta_{21}=0.445\right)$.

As PLS aims at explaining variances (Fornell and Bookstein, 1982), an evaluation of PLS-models has to apply prediction-oriented measures. Assessing the refined model, the $R$-squares of the dependent latent variables have to be interpreted. The $R^{2}$-values are 0.312 for the satisfaction construct, 0.320 for affective loyalty, and 0.430 for behavioral alty via satisfaction and affective loyalty is

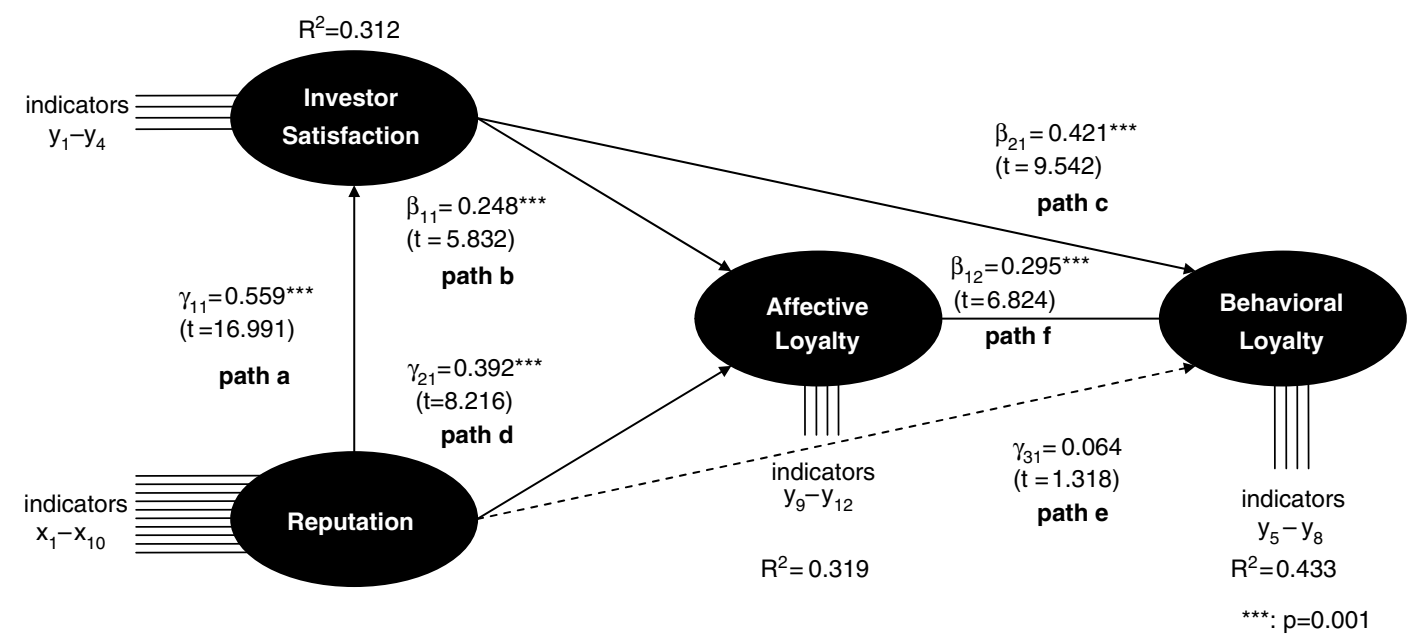

Figure 2: Information on the original model structure 


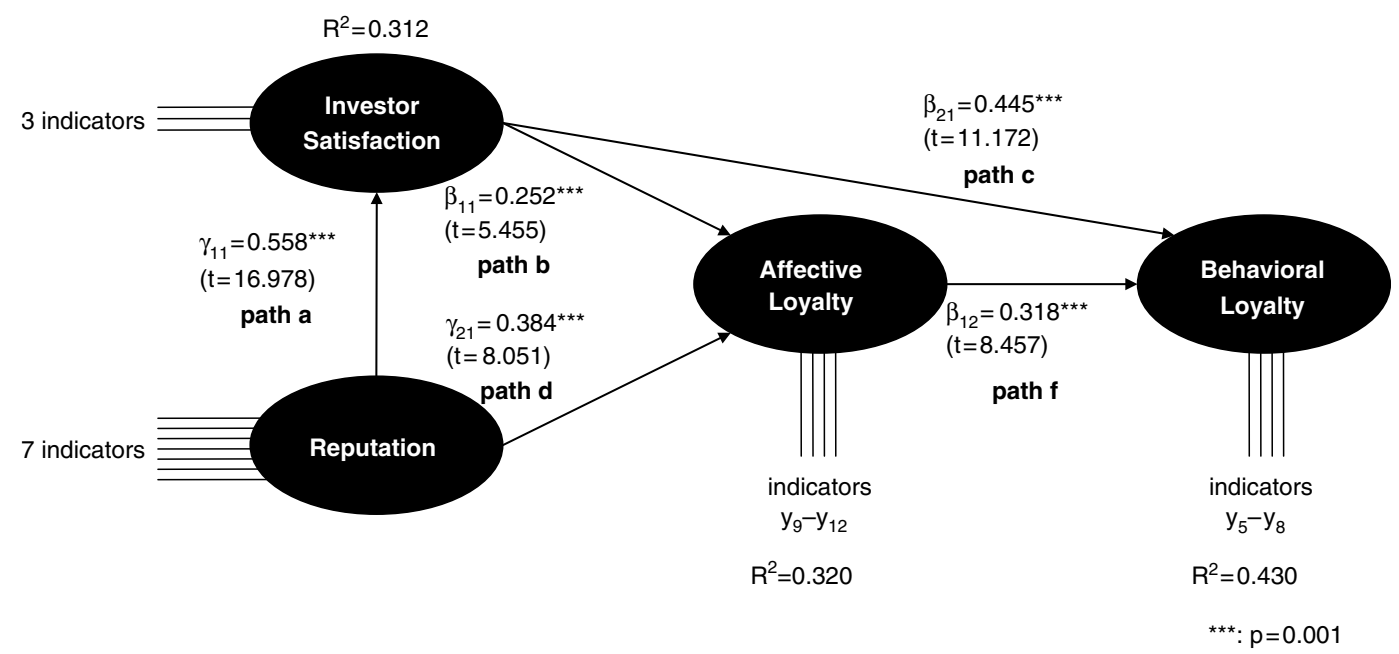

Figure 3: Information on the refined model structure

loyalty (see Figure 3). Within PLS-models, values above 0.1 are commonly deemed acceptable (eg Falk and Miller, 1992).

\section{DISCUSSION}

The present study contributes to a better knowledge of the interplay between corporate reputation, satisfaction of investors, and loyalty (research questions 1 and 2). Furthermore, the role of reputation in investment decision making can be discussed taking into account the study findings (research question 3).

All but one of the proposed relationships have been supported by the data. Taking into account reputation's considerable effect on affective loyalty, reputation might partly compensate for an investor's own experiences with a firm reflected in his/her degree of satisfaction, so that short-term deviations in share price or dividends paid do not lead to immediate downturn of the emotional predisposition of an investor towards his/her firm. This is especially noteworthy when taking into account the relatively low influence of satisfaction on affective loyalty. As confirmed by MacGregor et al. (2000), affective evaluations of a firm's reputation may result in a discounting of other information that should be incorporated into a judgment of the investment value of a firm. For corporate reputation management, this might imply that 'investing' in the firm's reputation has positive effects on the emotional predisposition of individual investors. This lever to improve affective loyalty has hitherto been neglected in reputation management, as well as investor relations.

While this finding strengthens behavioral finance scientists' opinion on the possibly misleading effect of emotions in investment decision making (Kahneman and Riepe, 1998; Shefrin, 2001), we have to take into account the other part of loyalty as well. As we ascertain, satisfaction's effect on behavioral loyalty is considerably stronger than its effect on affective loyalty. There is no significant effect of reputation on behavioral loyalty meaning that reputation is not a forceful lever to directly influence investors' future trading intentions or the holding period of shares. But one has to be aware that our study did not measure initial decision making on behalf of first-time buyers of shares who are usually focused on in works on behavioral finance. Also, the indirect effect of corporate reputation on behavioral loyalty via investor satisfaction needs to be taken 
into account. It is not a strong effect (only about 12 per cent of the variance of behavioral loyalty are explained by reputation), but given the assumed, paramount influence of financial performance data on the decision to sell or hold stocks, this impact of reputation as a qualitative determinant of investor loyalty is quite striking. The findings, however, also imply that 'good' companies' shares may after all not be held longer than bad companies' shares. Further evidence on reputation's role in investor decision making is called for to address research question number 3 more exhaustively.

Regarding the conceptualization of the constructs, the revelation of some weak indicators merits further attention. Concerning the satisfaction construct, the indicator termed 'development of the share price' did not contribute sufficiently to the construct. This might be due to the high market volatility and decreasing stock performance most investors had to face during the years prior to our study. Furthermore, the respondents might be more interested in the safety of their investment as the pronounced weights of the dividend and investment-oriented indicators suggest. The data did not indicate whether there were different types of investors according to their investment interests, though.

In respect of the reputation construct, we eliminated the items 'treatment of employees', 'customer orientation', and 'financial performance'. One might expect the former two items to be of minor relevance, they seem to influence investor's perception of the esteem a firm is held in to a minimal degree. The latter item - financial performance - was expected to be relevant, though. But while financial strength is an important factor to institutional investors (and analysts), it does not always have to be a decisive factor for individual investors (Gregory, 1998). As reported, individual investors did not name financial performance as a specific factor affecting their perception of a company's reputation in the preliminary interviews. Likewise, study respondents might have been of the opinion that financial performance data are not of interest to the public and consequently do not contribute to the creation of corporate reputation as perceived by the general public, whereas overall success of the company as captured in the indicator called 'corporate success' is very important in the creation of reputation. Within the set of reputation indicators, this one has the highest weight. In the eyes of individual investors, reputation is furthermore captured to a considerable degree by non-financial items such as 'commitment to social and charitable issues'.

\section{LIMITATIONS AND CONCLUSION}

In a behavioral research study like the current survey, common method bias is a potential problem that needs to be considered because such biases pose a rival explanation for the strength of the relationships between constructs (Podsakoff et al., 2003). Controlling for methods biases can refer to the design of the study procedures (ex ante techniques) or to statistical controls (ex post techniques). The latter are applicable to reflective models but pose considerable problems when formative construct measures are involved. While the 'goal of the statistical control procedures $[\ldots]$ is to obtain an estimate of the relationship between the constructs and measures that partials out the effect of method bias' (Podsakoff et al., 2003: $900)$, this is impossible concerning formative constructs because 'the method factor does not enter into the equation where the relationship between the formative measures and the construct is estimated' (Podsakoff et al., 2003: 900). The authors explain that the effects of method bias on formative constructs should be modeled at the construct level rather than at the item level - but unfortunately, such models are under-identified (Podsakoff et al., 2003). They therefore conclude that 'procedural controls are likely to 
be the most effective way to control common measurement biases' (Podsakoff et al., 2003: 900). Considering the study at hand, this was done by following a number of suggestions taken from the literature to remedy biases such as using introductory sections for each question (short 'cover stories' as proposed by Podsakoff et al., 2003), item randomization, multiple pretest steps to improve scale items including definitions of ambiguous terms (ie reputation) and testing for question simplicity and comprehensibility, using different scale endpoints and verbal labels for all points of the scales while assessing that none of these adaptations should jeopardize the validity of the scales.

A further possible obstacle is that the sample of our study was reduced to investors of one specific firm. An inter-sectoral study should be conducted to provide further insights, especially to find out more about reputation's impact on investor decision making and the assumption that individual investors 'irrationally' prefer 'good' companies' stocks. An analysis across companies and industries could also show whether there are industry effects on the influence of reputation onto satisfaction and loyalty. Specific types of investors might be satisfied with and/or loyal to stocks of companies with bad reputations or to companies that belong to an industry that is generally disliked (eg tobacco companies, companies producing weapons, oil companies). In these cases, individual investors might be attracted by other company/stock characteristics. Also, reliance on corporate reputation as a signal might be used to discern different types of individual investors as it might correlate with investors' affinity to accept risk levels. Also, it would be interesting to compare individual and institutional investors' perceptions of reputation and reputation's impact on their investment choices.

If reputation plays an important role in establishing relationships with investors, the dynamics of this effect might be investigated.
A longitudinal study could show how the importance of reputation evolves in an investor's relationship to a firm. As the data have provided evidence for an effect of reputation on satisfaction and affective loyalty, moderators of these effects might be taken into account. Such moderators might comprise investor involvement, expertise, income, wealth, investment strategy, prior share performance, etc. Also, cognitive dissonance that is deemed an important construct in behavioral finance might be included in future structural equation models to build a larger nomological network.

The present study extends previous research on reputation and investor behavior in two important ways. First, a model is proposed that incorporates novel concepts that have been hitherto neglected in research on reputation and on investor behavior alike. Few studies have attempted to address the antecedent factors leading to loyalty (Abdullah et al., 2000), or to investigate (long-term) investor behavior on a micro-level. Reputation has been found to have a direct influence on affective loyalty, and an indirect one on behavioral loyalty.

Second, by revealing evidence on the loyalty effect of reputation, the findings highlight the strategic importance of corporate reputation. In other stakeholder settings, loyalty is constantly considered a pre-economic performance measure and an overall success factor of the firm (eg Hallowell, 1996). Investor loyalty is interpreted as a factor in reducing volatility and cost of capital (Gregory, 1998). Furthermore, it might be associated with customer loyalty because 'investors are also consumers, and they talk to other consumers' (Hunt, 1952: 105). Uhl (1962) claims investors to be among the most loyal customers of a firm. Whether increasing investor loyalty does positively affect a firm's performance as we proposed at the outset of our investigation, remains to be studied, though. Owing to the distinctive interest in loyalty in other stakeholder 
settings, it certainly appears worthwhile to conduct research into this field which is so strongly connected to previous research endeavors in the discipline of behavioral finance.

\section{REFEREnCES}

Abdullah, M., Al-Nasser, A.D. and Husain, N. (2000) 'Evaluating functional relationship between image, customer satisfaction and customer loyalty using general maximum entropy', Total Quality Management, 11, 826-829.

Anderson, J.C. and Gerbing, D.W. (1991) 'Predicting the performance of measures in a confirmatory factor analysis with a pretest assessment of their substantive validities', Journal of Applied Psychology, 76, 732-740.

Anderson, E. and Sullivan, M. (1993) 'The antecedents and consequences of customer satisfaction for firms', Marketing Science, 12, 125-143.

Andreassen, T.W. (1994) 'Satisfaction, loyalty and reputation as indicators of customer orientation in the public sector', International Journal of Public Sector Management, 7, 16-34.

Andreassen, T.W. and Lindestad, B. (1998) 'The effect of corporate image in the formation of customer loyalty', Journal of Service Research, 1, 82-92.

Bagozzi, R. (1994) 'Structural equation models in marketing research: Basic principles', in R. Bagozzi (ed.), Principles of Marketing Research, Blackwell, Oxford, pp. 317-385.

Baker, H.K. and Haslem, J.A. (1973) 'Information needs of individual investors', Journal of Accountancy, 136, 64-69.

Baumgartner, H. and Homburg, C. (1996) 'Applications of structural equation modeling in marketing and consumer research: A review', International Journal of Research in Marketing, 13, 139-161.

Bem, D.J. (1967) 'Self-perception: An alternative interpretation of cognitive dissonance phenomena', Psychological Review, 74, 183-200.

Berens, G. and van Riel, C.B.M. (2004) 'Corporate associations in the academic literature: Three main streams of thought in the reputation measurement literature', Corporate Reputation Review, 7, 161-178.

Bloemer, J. and de Ruyter, K. (1998) 'Investigating drivers of bank loyalty: The complex relationship between image, service quality', International Journal of Bank Marketing, 16, 276-286.

Bollen, K. and Lennox, R. (1991) 'Conventional wisdom on measurement: A structural equation perspective', Psychological Bulletin, 110, 305-314.

de Bondt, W.F.M. (1998) 'A portrait of the individual investor', European Economic Review, 42, 831-844.
Bromley, D.B. (2002) 'Comparing corporate reputations: League tables, quotients, benchmarks, or case studies?', Corporate Reputation Review, 5, 35-50.

Brown, B. (1998) 'Do stock market investors reward companies with reputations for social performance?', Corporate Reputation Review, 1, 271-280.

Brown, B. and Perry, S. (1994) 'Removing the financial performance Halo from Fortunes "Most Admired" companies', Academy of Management Journal, 37, 1347-1359.

Cable, D. and Graham, M.E. (2000) 'The determinants of job seekers' reputation perceptions', Journal of Organizational Behaviour, 21, 929-947.

Chajet, C. (1997) 'Corporate reputation and the bottom line', Corporate Reputation Review, 1, 19-23.

Chin, W.W. (1998) 'The partial least squares approach to structural equation modeling', in G.A. Marcoulides (ed.), Modern Methods for Business Research, Lawrence Erlbaum, Mahwah/London, pp. 295-336.

Churchill, G.A. and Surprenant, C. (1982) 'An investigation into the determinants of customer satisfaction', Journal of Marketing Research, 19, 491-504.

Cohen, J., Cohen, P., West, S.G. and Aiken, L.S. (2003) Applied Multiple Regression/Correlation Analysis for the Behavioral Sciences, 3rd edn., Lawrence Erlbaum, Mahwah/London.

Deephouse, D.L. (1997) 'The effect of financial and media reputations on performance', Corporate Reputation Review, 1, 68-72.

Diamantopoulos, A. and Winklhofer, H.M. (2001) 'Index construction with formative indicators: An alternative to scale development', Journal of Marketing Research, 38, 269-277.

Dick, A.S. and Basu, K. (1994) 'Customer loyalty. Toward an integrated conceptual framework', Journal of the Academy of Marketing Science, 22, 99-113.

Dillman, D.A. (2000) Mail and Internet Surveys, 2nd edn., Wiley, New York.

Dowling, G.R. (2004) 'Corporate reputations: Should you compete on yours?', California Management Review, 46, 19-36.

Falk, R.F. and Miller, N.B. (1992) A Primer for Soft Modeling, University of Acron Press, Akron.

Festinger, L. (1957) A Theory of Cognitive Dissonance, Stanford University Press, Stanford CA.

Ferris, R. (1989) 'Why it's important to understand who owns stock', in D.R. Nichols (ed.), The Handbook of Investor Relations, McGraw-Hill Education, Homewood, pp. 173-181.

Fombrun, C. (1996) Reputation, Harvard Business School Press, Boston.

Fombrun, C., Gardberg, N. and Sever, J. (2000) 'The reputation quotient ${ }^{\mathrm{SM}}$ : A multi-stakeholder measure of corporate reputation', The Journal of Brand Management, 7, 241-255. 
Fombrun, C. and Shanley, M. (1990) 'What's in a name? Reputation building and corporate strategy', Academy of Management Journal, 33, 233-258.

Fornell, C. (1982) 'A second generation of multivariate analysis - An overview', in C. Fornell (ed.), A Second Generation of Multivariate Analysis, Greenwood Press, New York, pp. 1-21.

Fornell, C. and Bookstein, F.L. (1982) 'A comparison analysis of two structural equation models: LISREL and PLS applied to market data', in C. Fornell (ed.), A Second Generation of Multivariate Analysis, Greenwood Press, New York, pp. 289-324.

Gardberg, N. (2001) How Do Individuals Construct Corporate Reputations?, Unpublished Doctoral Dissertation, New York University, New York.

Goldberg, J. and von Nitzsch, R. (2001) Behavioral Finance, John Wiley, New York.

Gotsi, M. and Wilson, A.M. (2001) 'Corporate reputation: Seeking a definition', Corporate Communications, 6, 24-30.

Gregory, J.R. (1998) 'Does corporate reputation provide a cushion to companies facing market volatility? Some supportive evidence', Corporate Reputation Review, 1, 288-290.

Hair, J.F., Anderson, R.E., Tatham, R.L. and Black, W.C. (1998) Multivariate Data Analysis, 5th edn., Prentice Hall, Englewood Cliffs.

Hallowell, R. (1996) 'The relationships of customer satisfaction, customer loyalty, and profitability: An empirical study', International Journal of Service Industry Management, 7, 27-42.

Hammond, S.A. and Slocum, J.W. (1996) 'The impact of prior firm financial performance on subsequent corporate reputation', Journal of Business Ethics, 15, 159-165.

Hanson, D. and Stuart, H. (2001) 'Failing the reputation management test: The case of BHP, the big Australian', Corporate Reputation Review, 4, 128-143.

Helm, S. (2005) 'Developing a formative measure for corporate reputation', Corporate Reputation Review, 8, 95-109.

Hunt, P. (1952) 'A program for stockholder relations', Harvard Business Review, 30, 99-110.

Jarvis, C., MacKenzie, S.B. and Podsakoff, P.M. (2003) 'A critical review of construct indicators and measurement model misspecification in marketing and consumer research', Journal of Consumer Research, 30, 199-218.

Jöreskog, K.G. and Wold, H. (1982) 'The ML and PLS technique for modeling with latent variables - Historical and comparative aspects', in K.G. Jöreskog and H. Wold (eds.), Systems Under Indirect Oberservation, North Holland, Amsterdam, pp. 263-270.
Kahneman, D. and Riepe, M.W. (1998) 'Aspects of investor psychology', The Journal for Portfolio Management, 24, 52-65.

Kleinbaum, D.G., Kupper, L., Muller, K.E. and Nizam, A. (1998) Applied Regression Analysis and Other Multivariable Methods, 3rd edn., Duxbury Press, Pacific Grove.

Larsen, D. (2002) 'Determining the relationship between investor relations and reputation', 6th International Conference on Corporate Reputation, Identity and Competitiveness, Boston.

Levesque, T. and McDougall, G.H.G. (1996) 'Determinants of customer satisfaction in retail banking', International Journal of Bank Marketing, 14, 12-20.

Little, P. and Little, B.L. (2000) 'Do perceptions of corporate social responsibility contribute to explaining differences in corporate price-earnings ratios? A research note', Corporate Reputation Review, 3, 137-142.

MacGregor, D.G., Slovic, P., Dreman, D. and Berry, M. (2000) 'Imagery, affect, and financial judgment', The Journal of Psychology and Financial Markets, 1, 104-110.

MacKenzie, S.B., Podsakoff, P.M. and Jarvis, C. (2005) 'The problem of measurement model misspecification in behavioral and organizational research and some recommended solutions', Journal of Applied Psychology, 90, 710-730.

Martensen, A., Grønholdt, L. and Kristensen, K. (2000) 'The drivers of customer satisfaction and loyalty: Cross-industry findings from Denmark', Total Quality Management, 11, 544-553.

Mazzola, P., Gabbionta, C. and Ravasi, D. (2004) 'Exploring reputation on financial markets: A preliminary study', 8th International Conference on Corporate Reputation, Identity and Competitiveness, Fort Lauderdale.

Nguyen, N. and Leblanc, G. (2001) 'Corporate image and corporate reputation in customers' retention decision in services', Journal of Retailing and Consumer Services, 8, 227-236.

Oliver, R.L. (1999) 'Whence consumer loyalty?' Journal of Marketing, 63(Special Issue), 33-44.

Oliver, R.L. (1997) Satisfaction, McGraw-Hill, New York.

Podsakoff, P.M., MacKenzie, S.B. and Podsakoff, N.P. (2003) 'Common method biases in behavioral research: A critical review of the literature and recommended remedies', Journal of Applied Psychology, 88, 879-903.

Roberts, P.W. and Dowling, G.R. (2002) 'Corporate reputation and sustained financial performance', Strategic Management Journal, 23, 1077-1093.

Rossiter, J.R. (2002) 'The C-OAR-SE procedure for scale development in marketing', International Journal of Research in Marketing, 19, 305-335. 
Sabate, J.M. and Puente, E. (2003) 'Empirical analysis of the relationship between corporate reputation and financial performance: A survey of the literature', Corporate Reputation Review, 6, 161-177.

Sandberg, K. (2002) 'Kicking the tires of corporate reputation', Harvard Management Communication Letter, 5, 3-4.

Seltin, N. and Keeves, J.P. (1994) 'Path analysis with latent variables', in T. Husén and T. Postlethwaite (eds.), The International Encyclopedia of Education, 2nd edn., Pergamon, Oxford, pp. 4352-4359.

Shapiro, C. (1982) 'Consumer information, product quality, and seller reputation', Bell Journal of Economics, 13, 20-35.

Shefrin, H. (2001) 'Do investors expect higher returns from safer stocks than from riskier stocks?' The Journal of Psychology and Financial Markets, 2, 176-181.

Shefrin, H. (2002) Beyond Greed and Fear: Understanding Behavioral Finance and the Psychology of Investing, Oxford University Press, Oxford.

Shefrin, H. and Statman, M. (1984) 'The disposition to sell winners too early and ride losers too long', Journal of Finance, 40, 777-790.
Shefrin, H. and Statman, M. (1995) 'Making sense of beta, size, and book-to-market', The Journal of Portfolio Management, 21, 26-34.

Shiller, R.J. (2003) 'From efficient markets theory to behavioral finance', Journal of Economic Perspectives, 17, 83-104.

Shleifer, A. (2000) Inefficient Markets, Oxford University Press, Oxford.

Sobol, M.G. and Farrelly, G. (1988) 'Corporate reputation: A function of relative size or financial performance?' Review of Business \& Economic Research, 24, 45-59.

Spurgin, R. and Tamarkin, M. (2005) 'Switching investments can be a bad idea when Parrondo's paradox applies', Journal of Behavioral Finance, 6, 5-18.

Srivastava, R.K., McInnish, T.H., Wood, R.A. and Capraro, A.J. (1997) 'The value of corporate reputation: Evidence from the equity markets', Corporate Reputation Review, 1, 62-68.

Uhl, K.P. (1962) 'Shareowner brand preferences', Journal of Business, 35, 57-69.

Wartick, S.L. (2002) 'Measuring corporate reputation', Business \& Society, 41, 371-392.

Yoon, E., Guffey, H.J. and Kijewski, V. (1993) 'The effects of information and company reputation on intentions to buy a business service', Journal of Business Research, 27, 215-228. 